

\title{
Pengembangan Berpikir Kreatif dalam Aktivitas Pembelajaran pada Masa Pandemic Covid-19 melalui Media Quizizz
}

\author{
Asih Andriyati Mardliyah', Rizky Oktaviana E.P2, Fitriana Nadila ${ }^{3}$ \\ Universitas Islam Majapahit \\ e-mail: asihunim89@gmail.com
}

\begin{abstract}
Abstrak
Kebijakan Belajar dari Rumah telah menimbulkan permasalahan bagi para pendidik dan siswa SMK Palapa Mojokerto. Banyaknya guru yang masih kurang menguasai teknologi menjadi kendala dalam penyampaian materi dan tugas selama pembelajaran daring. Selama kegiatan belajar mengajar secara daring biasanya guru hanya mentranfer materi dan tugas via WA Group. Oleh karena itu pengabdian ini bertujuan untuk meningkatan pemahaman guru terhadap pengembangan berpikir kreatif serta membekali keterampilan kepada guru supaya dapat menggunakan media quiziz sebagai media pembelajaran untuk meningkatkan berpikir kreatif siswa. Pelaksanaan pengabdian kepada masyarakat ini menggunakan metode pendekatan dengan kegiatan pelatihan melalui media zoom dengan dua kali sesi, yakni sesi pertama, penyampaian materi berpikir kreatif, sesi kedua, penyampaian materi tentang quizizz. Hasil kegiatan pengabdian ini yaitu; Meningkatnya pengetahuan guru terhadap pengembangan berpikir kreatif dan keterampilan menggunakan media quizizz dalam proses pembelajaran.
\end{abstract}

Kata Kunci: Berpikir kreatif, Quizizz, Covid-19

\begin{abstract}
The Learning from Home Policy has caused problems for teachers and students of SMK Palapa Mojokerto. The number of teachers who still lack technology is an obstacle in delivering materials and assignments during online learning. During online teaching and learning activities, teachers usually only transfer materials and assignments via WA Group. Therefore, this devotion aims to increase teachers' understanding of the development of creative thinking and equip teachers with skills so that they can use quiziz media as a learning medium to improve students' creative thinking during the covid 19 pandemic. The implementation of this community service uses an approach method with training activities through media zoom with two sessions, namely the first session, delivering creative thinking material, the second session, delivering material on Quizizz. The result of the devotional activity is; Increased teacher knowledge on the development of creative thinking and skills using quizizz in the learning process.
\end{abstract}

Keyword: Creative Thinking, Quizizz, Covid-19 


\section{PENDAHULUAN}

Wabah Covid-19 telah membawa dampak yang besar bagi seluruh sektor kehidupan seperti ekonomi, sosial, agama, pendidikan dan sektor-sektor kehidupan yang lain. Untuk menghambat penyebaran Covid-19 maka sejak 16 Maret 2020, Pemerintah Indonesia memberlakukan Pembatasan Sosial Bersekala Besar (PSBB). Pemberlakuan PSBB dengan harapan agar dapat menghambat penularan virus covid-19. Mengikuti kebijakan PSBB tersebut, pemerintah juga mendorong kebijakan beribadah, belajar dan bekerja dari rumah yang kemudian lebih populer dikenal dengan Work Form Home (WFH).

Adanya pandemi covid-19 sangat berpengaruh terhadap dunia Pendidikan karena siswa diharuskan belajar dari rumah sebagai upaya pencegahan penularan covid-19. Untuk menghambat penyebaran Covid-19 pada siswa dan guru melalui kluster lembaga pendidikan, maka sekolah-sekolah melaksanakan kebijakan pemerintah untuk melakukan PSBB dengan cara Belajar dari Rumah (BDR). Salah satu sekolah yang menerapkan kegiatan Belajar dari rumah yakni Sekolah Menengah Kejuruan (SMK) Palapa Kabupaten Mojokerto.

SMK Palapa merupakan sekolah yang di bawah naungan Yayasan Bakri Adnan Zain yang beralamat di jalan raya Jabon KM.07. Kecamatan Mojoanyar Kabupaten Mojokerto. Sekolah ini memiliki tiga jurusan, yakni jurusan Teknik Komputer dan Jaringan, jurusan Teknik Kendaraan Ringan, dan jurusan Farmasi. Guru yang mengajar di SMK Palapa berjumlah 21 orang, dan jumlah keseluruhan siswa sebanyak 110 orang.

Pemberlakuan kebijakan Belajar dari Rumah (BDR) telah mengubah Proses Belajar Mengajar (PBM) dari yang sebelumnya dilaksanakan secara konvensional melalui tatap muka langsung menjadi modern dengan model daring. Sebelumnya siswa belajar dengan guru sebagai fasilitator dan pendamping, pada masa pandemic covid-19 berubah menjadi siswa secara mandiri belajar di rumah. Hal itu secara teoritis sesuai prediksi Sun, Tang, dan Zou (2020) yang menyebutkan bahwa karena covid-19 peserta didik dan pendidik, hingga orang tua harus melakukan kegiatan belajar dengan jarak jauh (Sun et al., 2020). Selain itu, perubahan tersebut juga membenarkan kesimpulan Maria Nicola dan kawan-kawannya ketika ia menyatakan: This Pandemi affects 90.2\% of students worldwide, in which 1.57 billion students are absent from school and 191 countries including Indonesia close the schools and change learning methods significantly by imposing learning at home through online learning system. (Nicola et al., 2020).

Kebijakan BDR menimbulkan permasalahan dikalangan para pendidik dan siswa SMK Palapa Mojokerto. Pasalnya, pembelajaran daring pada pandemic covid-19 ini merupakan hal yang baru sehingga banyak guru dan peserta didik yang merasa kesulitan untuk menerapkan pembelajaran daring. Berdasarkan hasil wawancara dengan salah satu guru di SMK Palapa terkait kendala pelaksanaan pembelajaran daring yakni, pertama, permasalahan yang muncul dari siswa yaitu permasalahan kuota dan sinyal. Hal ini dikarenakan 
rata-rata siswa SMK Palapa berasal dari keluarga yang kurang mampu. Meski sudah dapat bantuan kuota dari pemerintah namun tetap saja para siswa SMK Palapa kesulitan untuk melakukan pembelajaran daring karena mereka tidak memiliki alat komunikasi yang mendukung untuk KBM, serta faktor letak wilayah mereka tinggal yang sulit jaringan internet.

Kedua, permasalahan yang muncul dikalangan pendidik, yakni banyaknya guru yang masih kurang menguasai teknologi menjadi kendala dalam penyampaian materi dan tugas. Selama kegiatan belajar mengajar secara daring biasanya guru hanya mentranfer materi dan tugas via WA Group. Hal ini menyebabkan pemahaman materi oleh siswa kurang maksimal sehingga kualitas peserta didik pada masa pandemic ini dirasa berkurang. Hal yang sama juga dikemukakan Dewi bahwa terjadinya perubahan pembelajaran tatap muka ke pembelajaran online mempengaruhi daya serap informasi/pengetahuan yang diperoleh peserta didik (Dewi, 2020). Permasalahan yang terjadi di SMK Palapa tersebut juga pernah disampaikan dalam penelitian Aji bahwa pelaksanaan pembelajaran online dari rumah telah menimbulkan permasalahan yang dialami oleh pihak sekolah. Adapun permasalahan tersebut diantaranya adalah; 1) kurangnya penguasaan Teknologi Informasi oleh guru terutama guru yang sudah tua; 2) sarana dan prasarana yang kurang memadai untuk pembelajaran online; 3) akses internet yang terbatas; dan 4) kurang siapmya penyediaan anggaran (Aji, 2020).

Berdasarkan hasil observasi ke SMK Palapa, di masa new normal pandemic covid-19 saat ini, SMK Palapa sudah mulai melakukan aktivitas pembelajaran secara luring. Menurut penuturan Pak Djohan Wahyudi salah satu guru SMK Palapa jurusan komputer dan jaringan, pembelajaran luring mulai berjalan kembali karena pembelajaran daring dirasa kurang sesuai untuk siswasiswa SMK Palapa. Pertimbangan lain yang membuat SMK Palapa melakukan KBM secara luring karena untuk daerah Mojoanyar sendiri saat ini sudah menjadi daerah dengan zona hijau sehingga sekolah ini diperkenankan untuk melakukan KBM secara luring dengan mempertimbangkan protokol kesehatan. Pada pembelajaran luring kegiatan belajar mengajar hanya berlangsung selama 15 menit setiap mata pelajarannya. Singkatnya waktu yang digunakan dalam pembelajaran di masa new normal covid-19 ini tentu berefek pada hasil pembelajaran yang kurang maksimal. Maka dari itu, guru harus kreatif dalam KBM di masa new normal ini, supaya dengan waktu yang relatif singkat tersebut, siswa tetap dapat memahami materi ajar dengan baik.

Berbagai problematika yang telah dijelaskan di atas, diperlukan langkah strategis untuk mengatasi permasalahan tersebut. Maka dari itu, kegiatan pengabdian ini bertujuan untuk meningkatan pemahaman guru terhadap pengembangan berpikir kreatif serta membekali keterampilan kepada guru supaya dapat menggunakan media quiziz sebagai media pembelajaran untuk meningkatkan berpikir kreatif siswa. 


\section{METODE}

Mitra pada kegiatan pengabdian ini yaitu Sekolah Menengah Kejuruan (SMK) Palapa Mojokerto. SMK Palapa merupakan sekolah yang di bawah naungan Yayasan Bakri Adnan Zain yang beralamat di jalan raya Jabon KM.07 Kecamatan Mojoanyar Kabupaten Mojokerto. Sekolah ini memiliki tiga jurusan, yakni jurusan Teknik Komputer dan Jaringan, jurusan Teknik Kendaraan Ringan, dan jurusan Farmasi. Saat ini SMK Palapa dipimpin oleh Bapak Ahmad Sukrisno Akbar Hamdani, S.Pd., M.H. sebagai Kepala Sekolah (PLT).

Berdasarkan kesepakatan dengan sekolah mitra untuk menyelesaikan permasalah yang ada maka disepakati pelaksanaan pengabdian kepada masyarakat ini menggunakan metode pendekatan dengan kegiatan pelatihan. Kegiatan pelatihan ini dilaksanakan dengan menggunakan media zoom yang terdiri dari dua sesi yaitu; sesi pertama, penyampaian materi berpikir kreatif dengan tujuan memberikan pemahaman kepada guru SMK Palapa tentang hakikat berpikir kreatif dan cara pengembangan berpikir kreatif siswa. Sesi kedua, penyampaian materi tentang Quizizz dengan tujuan mengenalkan media Quizizz kepada guru SMK Palapa kemudian dilanjutkan praktek penggunaan media quiziz. Kegiatan pelatihan ini di ikuti sebanyak 6-8 guru SMK Palapa.

\section{HASIL DAN PEMBAHASAN}

Hasil yang dicapai dari kegiatan pengabdian kepada masyarakat ini diantaranya adalah sebagai beriku.

1. Meningkatnya pemahaman dan sikap positif guru terhadap pengembangan berpikir kreatif.

Pada kegiatan pengabdian ini terdiri dari dua sesi. Sesi pertama yakni penyampaian materi berpikir kreatif dengan tujuan memberikan pemahaman kepada guru SMK Palapa tentang hakikat berpikir kreatif dan cara pengembangan berpikir kreatif siswa. Materi ini disampaikan oleh Rizky Oktaviana EP, M.Pd. Pada sesi pertama ini, Ibu Rizky menyampaikan bahwa SMK merupakan bagian dari sistem pendidikan nasional yang memiliki tujuan pendidikan kejuruan yaitu menghasilkan tenaga terampil yang memiliki kemampuan sesuai dengan tuntutan kebutuhan dunia usaha/industri. Selain itu lulusan SMK juga dituntut untuk mampu mengembangkan potensi dirinya dalam mengadopsi dan berdaptasi dengan perkembangan ilmu pengetahuan, teknologi dan seni. Berdasarkan tuntutan yang dijelaskan sebelumnya maka secara tidak langsung lulusan SMK memiliki kemampuan kreativitas yang lebih dibandingkan dengan lulusan pada tingkat SMA/MA. Aspek Kreativitas ini sudah dicanangkan dalam 9 area kompetensi lulusan SMK dimana dalam aspek ini diharapkan lulusan SMK:

a. Memiliki kemampuan untuk mencari dan menghasilkan gagasan, cara kerja, layanan dan produk karya inovatif sesuai dengan keahliannya. 
b. Memiliki kemampuan bekerjasama menyelesaikan masalah dalam melaksanakan tugas sesuai keahlian secara kreatif.

Dewey menyatakan bahwa berpikir kreatif dipandang sebagai sebagai proses pemecahan masalah mulai dari mengidentifikasi masalah sampai menemukan solusi (Dewey, 1920). Sedangkan (Glass, 2004) menyatakan berpikir kreatif adalah serangkaian aktivitas kognitif yang dilakukan seseorang sesuai dengan permasalahan yang dihadapi. Hal ini ditegaskan juga oleh (Kampylis P. \& Berki E, 2014) bahwa berpikir kreatif adalah berpikir yang memungkinkan siswa mengaplikasikan imaginasi mereka untuk menghasilkan ide, hipotesis lalu mengevaluasinya. Berdasarkan definisi berpikir kreatif yang telah disebutkan tersebut terlihat bahwa proses berpikir kreatif berhubungan dengan penyelesaian masalah yang dihadapi. Pelatihan ini diharapkan guru-guru dapat memahami tentang pentingnya berpikir kreatif serta dapat melatihkan ke peserta didik sehingga kompetensi utama dari kurikulum dapat tercapai.

2. Meningkatnya pengetahuan dan sikap positif serta keterampilan guru terhadap pemanfaatan media pembelajaran Quizizz untuk meningkatkan berpikir kreatif siswa.

Setelah sesi pertama selesai kemudian dilanjutkan dengan sesi ke dua yakni penyampaian materi tentang Quizizz dengan tujuan mengenalkan media Quizizz kepada guru SMK Palapa kemudian dilanjutkan praktek penggunaan media quiziz dalam pembelajaran. Kegiatan ini langsung dipandu oleh Asih Andriyati Mardliyah, M.Pd. Pada sesi ini pemateri (Ibu Asih) berusaha mengenalkan media pembelajaran quizizz dengan harapan pengetahuan guru terhadap media digital (Quizizz) bertambah serta guru dapat memanfaatkan media quizizz ini sebagai penunjang proses pembelajaran agar siswa merasa tidak jenuh dengan aktivitas pembelajaran yang kurang menarik/kurang kreatif. (Mei et al., 2018) mengungkapkan bahwa aplikasi Quizizz mampu meningkatkan hasil belajar dan motivasi peserta didik. Senada dengan Mei, Rahman mengungkapkan bahwa pemanfaatan media quizizz dapat memotivasi belajar peserta didik dalam masa Covid-19 (Rahman et al., 2020). Selain itu, Nurhayati menambahkan bahwa pembelajaran daring dengan quizizz mampu meningkatkan keaktifan peserta didik (Nurhayati, 2020). Melalui media quizizz diharapkan pembelajaran dapat berjalan dengan menarik, tidak membosankan, serta hasil pembelajaran tetap dapat maksimal meskipun waktu pembelajaran selama pandemic ini dirasa sangat kurang.

Quizizz merupakan sebuah web tools untuk membuat permainan kuis interaktif yang digunakan di dalam pembelajaran di kelas. Berdasarkan hasil kegiatan pengabdian ini diketahui bahwa guru-guru di SMK Palapa belum mengetahui tentang media quizizz ini. Hal ini tampak dari pertanyaan beberapa guru kepada pemateri tentang apa itu quizizz. Padahal media quizizz sudah cukup lama ada dan telah banyak digunakan pada pembelajaran. Penggunaan aplikasi interaktif (Permainan) seperti Quizizz 
ini sesungguhnya mempermudah guru dalam mengelola pembelajaran dan menyampaikan informasi secara cepat dan akurat kepada siswa, apalagi aplikasi quizizz memang dikonsep seperti game dimana hampir semua orang (khususnya remaja) suka akan game. Dellos menyatakan bahwa pembelajaran berlandasan permainan merupakan alat yang dapat membantu peserta didik dalam menyelesaikan masalah, meningkatkan pemikiran kritis dan membuat sebuah penilaian dalam proses pembelajaran (Dellos, 2015). Quizizz sendiri merupakan aplikasi interaktif yang menyenangkan, real time karena bisa langsung mendapatkan hasilnya serta bisa sebagai alternative evaluasi pembelajaran, atau PR dan dapat dipantau analisis perbutir soalnya.

Setelah meningkatkan pengetahuan guru SMK Palapa tentang quizizz serta menumbuhkan sikap positif guru SMK Palapa terhadap pemanfaatan media quizizz dalam proses pembelajaran, selanjutnya guru diberikan pelatihan untuk membuat akun quizizz, membuat soal secara mandiri, cara menggunakan soal yang sudah tersedia, cara menugaskan ke siswa serta cara membaca nilai (hasil). Melalui pelatihan ini maka guru SMK Palapa dapat meningkatkan pengetahuan dan keterampilan dalam memanfaatkan teknologi dalam pembelajaran daring mengingat selama ini pembelajaran terbatas melalui media Whatsapp. Berikut salah satu contoh tampilan quizizz setelah guru login.

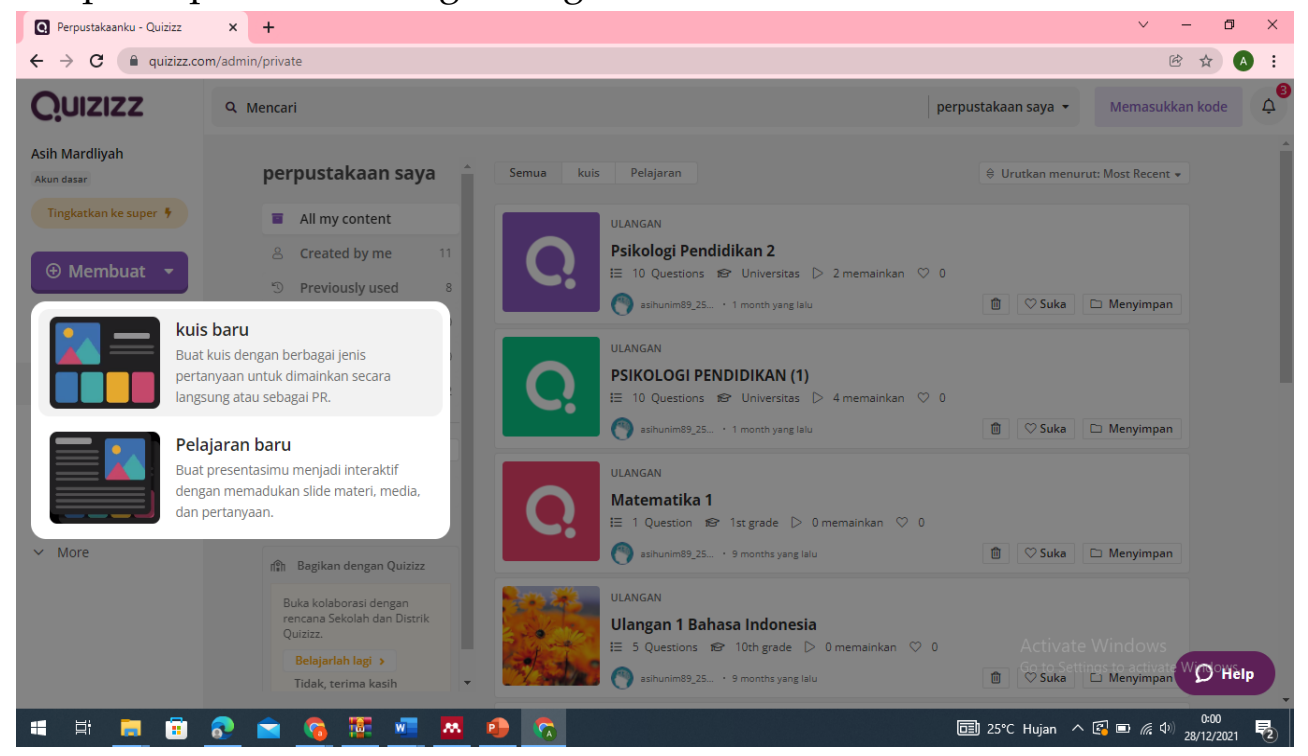

Gambar 1. Gambar tampilan aplikasi quizizz.

\section{SIMPULAN}

Kegiatan pengabdian ini bisa dikatakan berjalan sangat baik, mulai dari persiapan hingga pelaksanaan berjalan dengan lancar. Mitra pengabdian (SMK Palapa) memberikan respon dan sambutan yang positif terhadap kegiatan pengabdian ini. Guru-guru yang mengikuti pelatihan ini juga antusias dengan pengetahuan akan media quizizz, mereka juga tertarik untuk menggunakan quizizz dalam pembelajaran. Kendala yang dihadapi selama pelatihan ini adalah koneksi yang belum stabil sehingga penyampaian materi terganggu. 


\section{DAFTAR PUSTAKA}

Aji, R. H. S. (2020). Dampak Covid-19 pada Pendidikan di Indonesia: Sekolah, Keterampilan, dan Proses Pembelajaran. SALAM: Jurnal Sosial Dan Budaya Syar-I, 7(5), 395-402. https:// doi.org/10.15408/sjsbs.v7i5.15314

Dellos, R. (2015). Kahoot! A digital game resource for learning. International Journal of Instructional Technology and Distance Learning, 12, 49-52.

Dewey, J. (1920). Creative democracy: The task before us. American Education Press, Incorporated.

Dewi, W. A. F. (2020). Dampak COVID-19 terhadap Implementasi Pembelajaran Daring di Sekolah Dasar. EDUKATIF : JURNAL ILMU PENDIDIKAN, 2(1), 55-61. https:/ / doi.org/10.31004/edukatif.v2i1.89

Glass, T. . F. (2004). What gift? The reality of the student who is gifted and talented in public school classrooms. Gifted Child Today, 27(4), 25-29.

Kampylis P., \& Berki E. (2014). Nurturing creative thinking. International Academy of Education, UNESCO, 6. http://unesdoc.unesco.org/images/0022/002276/227680e.pdf

Mei, S. Y., Ju, S. Y., \& Adam, Z. (2018). Implementing Quizizz as Game Based Learning in the Arabic Classroom. European Journal of Social Sciences Education and Research, 12(1), 208. https:// doi.org/10.26417/ejser.v12i1.p208-212

Nicola, M., Alsafi, Z., Sohrabi, C., Kerwan, A., Al-Jabir, A., Iosifidis, C., Agha, M., \& Agha, R. (2020). The socio-economic implications of the coronavirus pandemic (COVID-19): A review. International Journal of Surgery, 78(March), 185-193. https:/ / doi.org/10.1016/j.ijsu.2020.04.018

Nurhayati, E. (2020). Meningkatkan Keaktifan Siswa Dalam Pembelajaran Daring Melalui Media Game Edukasi Quiziz pada Masa Pencegahan Penyebaran Covid-19. Jurnal Paedagogy, 7(3), 145. https:/ / doi.org/10.33394/jp.v7i3.2645

Rahman, R., Kondoy, E., \& Hasrin, A. (2020). Penggunaan Aplikasi Quizziz Sebagai Media Pemberian Kuis Dalam Meningkatkan Motivasi Belajar Mahasiswa. JISIP (Jurnal Ilmu Sosial Dan Pendidikan), 4(3), 60-66. https://doi.org/10.36312/jisip.v4i3.1161

Sun, L., Tang, Y., \& Zuo, W. (2020). Coronavirus pushes education online. Nature Materials, 19(6), 687. https:/ / doi.org/10.1038/s41563-020-0678-8 